\title{
The Misconceptions Recognized from My Business Studies in China and Abroad
}

\author{
Wenkai Zhou \\ M.B.A. Candidate, Class of 2013, A. Gary Anderson Graduate School of Management, \\ University of California, Riverside, wenkai.zhou@email.ucr.edu
}

\begin{abstract}
Four year overseas studies and Chinese background made me be aware of the presence of many misconceptions in the understanding of Chinese business, traditional culture and education. Certain theories related to politics or military like "thick face, black heart" and "Sun Tzu on the art of war" are exceedingly expanded to the profit-orientated business. A traditional culture fever in China actually reflects the need for solving some problems. Chinese education still has a long way to go in enhancing its practice. The hi-tech means in use of internet leads to a more objective study than the previous literature-based only.
\end{abstract}

Keywords: Misconception, business, culture, education, hi-tech

\section{Introduction}

China has attracted lots of international authors' attention [1]-[4] due to its great increase in economy for the past tens of years. Two and a half years of undergraduate studies in Eastern Washington University and one and a half years of postgraduate studies in University of California at Riverside made me, an MBA candidate of 2013, be capable of perusing many those English papers about Chinese business or businessmen in the west view.

Meanwhile, the booming market economy largely stimulated the self-awareness of the benefited Chinese as well. A tradi- tional culture fever has spread nationwide for years [5], [6]. The Chinese background and the previous one and a half years of undergraduate studies in Chang' an University, China, enabled me to understand and speculate about these reasonably in combination with what happen abroad.

In fact, as shown by my studies and experiences, certain fallacies are present in the general understanding of Chinese businessmen and related culture. The agitation returning to some traditional values in China is also problematic to a certain extent. Chinese education generally lacks practice in comparison with the west counterpart or needs some reforms. The previous study methodologies on the basis of literatures only [7] are obsolete owing to the wide use of current hi-tech communication means

The pertinent recognitions are briefly clarified as follows.

\section{Misconceptions in business studies}

\subsection{Over-stressed culture factors}

The standards and values set by Confucius thousands of years ago are believed to have permeated Chinese culture or been the root [1]-[3]. The collectivism or certain peasant farming-related agrarian values are further recognized as other kernel of Chinese culture [2], [3]. These are true, but the pertinent influence on the behavior of current Chinese are actually exaggerated to a large extent. 
First, China had two nationwide revolutions in culture. The May Fourth Movement in 1919, though mainly positive, largely suppressed the traditional culture [7]. The culture revolution set by Mao between 1966 and 1976 seriously altered it once more and the impact was negative. Now China is actually deficient in some of the virtues initiated by Confucius like benevolence, righteousness and trustworthiness. e.g., few are willing to help a fallen-down elder due to worrying about being extorted.

Second, the booming market economy has made numerous Chinese moneyorientated though business was viewed as a branch deviated from the root (agriculture) and long slighted [3]. The traditional culture fever partly reflects the social expectations for more virtues [5], [6].

Third, a business behavior is in fact defined by many factors while the cultural one may be negligible. e.g., many people have the country-of-origin consciousness for a product [8]. Chinese mostly prefer the goods from German or Japan [9]. But the recent territory dispute may make them hesitate to buy a Japanese product. Broad Americanization in the youth additionally weakens the influence of traditional culture [10].

Last, Chinese images have actually changed many times from the American views between 1784 and 1971 owing to the change of China [11]. But the traditional culture in fact stays as the same. This strongly suggests a limited influence of traditional culture on people.

\subsection{Misled into politics or military}

The highly shameless nature for certain ancient Chinese politicians was referred to as "thick face", while the extreme brutality as "black heart" [4]. These with some military-originated tricks like thirty six stratagems or Sun Tzu's art of war were limitless connected to Chinese business [12], [13]. This is incorrect.
In essence, business is profit-orientated, whereas politics or especially the military aims to destroy the enemy. The former is based on bilateralism and the latter on conquering. Their natures are completely different.

Moreover, there are also many good traditions in Chinese business, but those are seldom properly mentioned. For instance, numerous old sayings are very popular in China and have long been advocated [9], such as "a gentleman loves the fortune, but he only try to get it in a proper way” (君子爱财取之有道), “a very old or a very young person should be treated as the same as an adult in business" (童舅无欺) and so on.

Chinese merchants are usually grouped into several factions on the basis of their origins or gathering and basic cooperation, especially in the ancient time. Some are well known as Jin Merchants (mostly originated from Shanxi Province, Jin is the old alias for Shanxi), Hui Merchants (mainly from Anhui Province), Zhe Merchants (basically from Zhejiang Province) and so on. They are characterized by their own creeds that made them prosperous [14]. e.g., "faith is the supreme" (信义至 上) marked Jin Merchants. Those are mostly connected to trustworthiness and endeavor, but little to do with political or military tricky stratagems.

\section{Needs disguised with a culture fever}

As aforementioned, a cultural movement spread over China in 1919, which was identified by rejecting or criticizing the traditions [7]. The recent culture fever, however, results from the mass expectation backing to certain social order existed in the ancient time. It actually manifests the fact that people are greatly confused when confronting the numerous problems caused by fast economic development in environment, values, interpersonal relationship, etc. 
Taoism, occurred somewhat earlier than Confucianism, is a philosophy about the law between nature and human being [15], which, besides Confucianism, is the other kernel of Chinese culture. Although people learn Taoism mainly for a health care purpose, most of them still expect to find a solution for the continuously worsened troubles like food and air pollutions, nature resources-abuse, etc., or be able to live in harmony with the nature. Alternatively, the main objective of learning Confucianism is to know how to behave, cope with interpersonal relationship and make friends appropriately [6] in the modern society of being full of competition and struggles.

\section{The education lacking practice}

The great development in tertiary education is broadly regarded as one of important achievements gained from the economic reform in the past tens of years in China. But the educational quality is generally neglected.

In 1988 , there were 1,075 so-called ordinary higher educational institutions in total in China and the relevant full-time students amounted to two millions and one hundred sixty thousands $(2,160,000)$ [16], but 1,073 adult higher educational institutions and related one million and seven hundred thirty thousands of students $(1,730,000)$ were not included. The total number for the colleges and universities would amount to 2,148 and the students to three millions and eight hundred ninety thousands $(3,890,000)$ in 1988 if those two were summed together. Twenty two years later or in 2010 , the number for the ordinary higher educational institutions increased to 2,358 and that for the adult reduced to 365 or the total number was 2,723 on the basis of the government website [17]. The students for the both amounted to thirty one millions and fifty thousands $(31,050,000)$.
Clearly, the increase rate for the colleges and universities is 26.1 tertiary institutions per year and this is not so worse. However, the rate in the student sense is $1,234,545.45$ persons per year on earth. The educational quality can be readily estimated from the fact that one million and nearly two hundred forty thousands of students have been added to Chinese colleges and universities annually for twenty two years.

Chinese education highly lacks practice and students are mainly confronted with too many courses in classroom. This can be specified by the below example.

In December, 2009, I came back to the Chinese university in which I studied and saw that my friends did their dissertations only based on the data from internet and publications. On the contrary, as a student in the senior Capstone class, College of Business \& Public Administration, Eastern Washington University, I did my dissertation through data retrieval, questionnaire, face-to-face investigation, feasibility studies and design in earlier time. Five other students in the research project were Americans and I took the lead in team task scheduling and in writing the business plan. The project aimed to plan a one-stop home energy conservation store in one of Spokane's rebuilding neighborhoods, which included the City's remaining industrial park land. The ideal result was that the store would serve residents from all parts of town and the surrounding area by using energy conservation products that could be manufactured locally in the industrial park area. Eventually the team figured out an excellent business plan for it.

\section{Hi-tech communication means and related all-round studies}

The present time is marked by hi-tech communication means. Internet and wireless or microwave is the kernel. The 
communication is largely intensified by many specific techniques, such as broad band, blue tooth, cell phone, WiFi (wireless-fidelity), etc.

These can cause a quality change for research doubtlessly. e.g., previous China studies or the sinology is mainly based on bibliography and theoretical analyses [5]. Now it can be done through internet questionnaire or video interview, short message or cell phone investigation, etc. A direct communication and broader scope may increase the objectiveness, and worldwide exchange of ideas can largely diminish the influence of any traditional cultures [9]. This needs well thinking in future studies.

\section{References}

[1] A. Chan, "Confucianism and Economic Development in East Asia," Journal of Contemporary Asia, vol. 26, no. 1, pp. 28-45, 1996.

[2] C. A. Rarick, "Confucius on Management: Understanding Chinese Cultural Values and Managerial Practices," Journal of International Management Studies, no. 8, pp. 22-28, 2007.

[3] J. L. Graham and N. M. Lam, "The Chinese Negotiation," Harvard Business Review, vol. 81, no. 10, pp. 8291, 2003.

[4] L. S. Pheng, "Thick Face, Black Heart and the Marketing of Construction Services in China," Marketing Intelligence \& Planning, vol. 15, no. 5, pp. 221-226, 1997.

[5] R. H. Wang and R. W. Huang, China Studies (in Chinese with English abstract). Shanghai: Xuelin Press, pp. 117, 2007.

[6] D. Yu, Yu's Notes of Reading the Analects of Confucius (in Chinese). Beijing: China Press, pp.1-117, 2009.
[7] Y. S. Yan (Ed.), The Representative Works of Hu Shi (in Chinese). Hefei: Anhui Education Press, vol. 1-3, 2007.

[8] S. A. Ahmed and A. Astous, "Antecedents, Moderators and Dimensions of Country-of-origin Evaluations," International Marketing Review, vol. 25, no. 1, pp. 75-106, 2008.

[9] W. K. Zhou, "The Business Negotiation Viewed from both Western and Chinese Cultures" (in Chinese with English abstract), Economic Research Guide, no. 3, pp. 159-163, 2010.

[10] C. S. Craig, S. P. Douglas and A. Bennett, "Contextual and Cultural Factors Underlying Americanization," International Marketing Review, vol. 26, no. 1, pp. 90-109, 2009.

[11] M. Yuan, "A Brief Look at China's Image in the United States" (in Chinese with English abstract) in American Studies, vol. 3, no. 1, pp. 16-23, 1989.

[12] T. Fang, "Negotiation: the Chinese Style," The Journal of Business \& Industrial Marketing, vol. 21, no. 1, pp. 50-60, 2006.

[13] G. Gagliardi, Sun Tzu's the Art of War for the Business Warrior: Strategy for Entrepreneurs. Seattle: Clearbridge Publishing, 2006.

[14] Z. Hong, The Chinese Philosophy of Merchants (in Chinese). Haerbin Press, pp. 56-63, 110-146, 2009.

[15] K. S. Yip, "Taoism and its Impact on Mental Health of the Chinese Communities," International Journal of Social Psychiatry, vol. 50, no. 1, pp. 25-42, 2004.

[16] M. Y. Gu (Chief Ed.), The Educational Dictionary of China (in Chinese with English index). Shanghai Education Publishing, vol. 3, pp. 3-17, 1991.

[17] http://www.moe.gov.cn/ 